\title{
Bioleaching of low grade granitic chalcopyrite ore by hyperthermophiles: Elucidation of kinetics-mechanism
}

\author{
Abhilash, A. Ghosh and B.D. Pandey \\ CSIR-National Metallurgical Laboratory, Jamshedpur, India \\ e-mail: abhibios@gmail.com
}

Key words:

Chalcopyrite ore; bioleaching; pyrite; hyper thermophiles; archaea

\begin{abstract}
The current work was off-shoot of an attempt to isolate a thermophilic pyritic sulfur degrading bacteria in selective medium from a coal mine dump. This thermophilic bacteria (archaea) classified as Sulfolobus was tested for its feasibility to bioleach copper from a low grade Indian chalcopyrite ore $(0.3 \%$ copper). With its prevalent ability to preferentially attack pyrite (a major phase in the ore), bioleaching was investigated at various parameters of $\mathrm{pH}$, pulp density (PD), particle size, and temperature. A reflective high $85 \%$ copper recovery was obtained using $<50 \mu \mathrm{m}$ particles at $20 \%$ (w/w) pulp density, $\mathrm{pH} 2.0$, $75^{\circ} \mathrm{C}$ in 30 days. The copper dissolution was facilitated by iron (III) available in the leach liquor because of bacterial oxidation of pyrite present in the ore under acidic conditions. The biogenically generated Fe (III) ions enhanced copper dissolution from the chalcopyrite ore. The bioleaching of copper appeared to follow chemical control kinetic model with the reaction of lixiviant-Fe (III) and acid on the surface of the solid. Phase identification by XRD and SEM study corroborated the above mechanism of copper leaching.
\end{abstract}

Received 27 March 2015
Accepted 12 August 2015

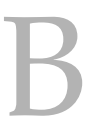
iohydrometallurgy has been studied extensively since last three decades covering its role for various metals and varied resources $[1,2]$. Bioleaching has also faced technical issues in scale-up and commercialization for its slower rate. It was reported that microbes with high tolerance to metal ions promoted leaching efficiency and thus all experiments with pure species compared their efficacy with the ones carried with adapted microbes [3]. Different ores and concentrates have been tested to be amenable to leaching of copper, nickel, zinc, cobalt, uranium by acidophilic microorganisms in single or by mixed cultures of different species of both mesophilic and thermophilic microbes [2]. Temperature and ferric concentration greatly influence the efficiency of the chalcopyrite leaching $[5,6]$. In mesophilic conditions, ferric ions are effective for leaching chalcopyrite with bacteria maintaining high ferric to ferrous ratio and a high redox potential [4].

There are two dominant views on the mechanisms involved in bioleaching of copper [7-9]. The first is that the overall leaching process occurs by the microbial oxidation of ferrous to ferric ions followed by the chemical oxidation of the sulfide mineral by the ferric ion. This is known as the indirect mechanism. The second view envisages the microbial catalysis of the overall dissolution of the mineral. It has been proposed that the microorganisms interact with the mineral directly, enhancing the rate of oxidation, over and above that achieved by chemical oxidation. This is known as the direct mechanism. Regardless of the mechanism, it is the enhanced oxidation of the mineral created by the microorganism that creates the acidsolubility required for leaching to take place.

The overall chemical reactions for chalcopyrite are:

$$
\begin{gathered}
4 \mathrm{CuFeS}_{2}+11 \mathrm{O}_{2}+6 \mathrm{H}_{2} \mathrm{O} \longrightarrow 4 \mathrm{CuSO}_{4} \\
+4 \mathrm{Fe}(\mathrm{OH})_{3}+4 \mathrm{~S} \\
2 \mathrm{~S}+3 \mathrm{O}_{2}+2 \mathrm{H}_{2} \mathrm{O} \longrightarrow 2 \mathrm{H}_{2} \mathrm{SO}_{4} .
\end{gathered}
$$

It should be noted that one of the problems that has had to be overcome in the leaching of chalcopyrite was that, when using natural bacteria, a passivating layer 
forms on the mineral surfaces that prevents further leaching [10-13]. This passivating layer could come from one or both of two sources: $\mathrm{Fe}(\mathrm{OH})_{3}$ tends to form jarosite $\left(\mathrm{KFe}_{3}\left(\mathrm{SO}_{4}\right)_{2}(\mathrm{OH})_{6}\right)$, which coats the unreacted material and forms a passivating layer and/or, the elemental sulfur formed in reaction (1), which also tends to coat the surface. It has been found from fundamental electrochemistry that the newer technology, using thermophilic microorganisms such that the temperature can be raised to $60^{\circ} \mathrm{C}\left(140{ }^{\circ} \mathrm{F}\right)$ or higher, destabilizes the passivating layer on chalcopyrite [14-17]. Higher extractions have been achieved [18-20] using extremely thermophilic archaea growing at higher temperatures $\left(60-85^{\circ} \mathrm{C}\right)$. The oxidation reactions involved in the solubilization of mineral sulphides are exothermic; hence the ability of the thermophiles to grow at higher temperatures is advantageous in providing an improved driving force for heat removal. In addition, enhanced oxidation kinetics in terms of rate of reaction and extent of solubilization is a potential advantage of thermophilic bioleaching [21-23]. The extent of leaching of base metals such as copper from refractory sulphidic minerals is greatly increased by the implementation of increased temperature. Thermophiles like Sulfolobus, Acidianus and Metallosphaera have been shown to leach chalcopyrite better at $65-75^{\circ} \mathrm{C}[23,24]$, in shake flask mode. Application of these thermophiles has been widely reported in metal biodissolution processes, especially in copper bioleaching from chalcocite and covellite [22]. However, a scanty work has been found for low grade chalcopyrite $[5,6]$, which is considered otherwise difficult to be processed by conventional hydrometallurgical route [2].

In this work, an enriched culture of thermophile, Sulfolobus was isolated from the coal mine dumps at $75^{\circ} \mathrm{C}$ with the objective of depyritisation of coal. The preferential growth in presence of pyrite made us apply this microbe to a metal rich environment of chalcopyrite $(0.3 \% \mathrm{Cu})$ from Malanjkhand granitic copper ore and test its feasibility to microbially dissolve copper under various parameters like $\mathrm{pH}$, pulp density, particle size and temperature in presence and absence of bacteria.

\section{Materials and methods}

\subsection{Ore sample}

Low tenor granitic hard copper ore (containing $0.3 \% \mathrm{Cu}$ ) was collected in the form of lumps from Malanjkhand copper mine (located in Balaghat, Madhya Pradesh, India). The ore was crushed, ground and passed through a sieve of $50 \mu \mathrm{m}$ size. The bioleaching experiments were carried out with this material unless stated otherwise. A representative sample was then prepared by coning and quartering for chemical analysis by atomic absorption spectrometer [5]. The phase identification by XRD showed that $\mathrm{CuFeS}_{2}$ (chalcopyrite), $\mathrm{FeS}_{2}$ (pyrite) and $\mathrm{SiO}_{2}$ (quartz) were the major mineral phases and $\mathrm{Cu}_{5} \mathrm{FeS}_{4}$ (bornite) as a minor mineral phase in the ore. SEM micrograph of the ore is shown in Figure 1, which clearly indicates the presence of $\mathrm{Cu}, \mathrm{Ni}, \mathrm{Co}, \mathrm{Fe}$ in predominant alumino-silicate matrix.

\subsection{Microorganism}

Enriched culture of a thermophilic archaea was isolated from dumps of coal mines, India in medium containing $\left(\mathrm{NH}_{4}\right)_{2} \mathrm{SO}_{4}-1.3 \mathrm{~g} / \mathrm{L}, \quad \mathrm{KH}_{2} \mathrm{PO}_{4}: 0.028 \mathrm{~g} / \mathrm{L}$; $\mathrm{MgSO}_{4} .7 \mathrm{H}_{2} \mathrm{O}-0.025 \mathrm{~g} / \mathrm{L} ; \quad \mathrm{CaCl}_{2} \cdot 2 \mathrm{H}_{2} \mathrm{O}-$ $0.07 \mathrm{~g} / \mathrm{L} ; \mathrm{MnCl}_{2} .4 \mathrm{H}_{2} \mathrm{O}-1.8 \mathrm{mg} / \mathrm{L} ; \mathrm{FeCl}_{2} .6$ $\mathrm{H}_{2} \mathrm{O}-0.02 \mathrm{~g} / \mathrm{L} ; \mathrm{Na}_{2} \mathrm{~B}_{4} \mathrm{O}_{3} .10 \mathrm{H}_{2} \mathrm{O}-4.5 \mathrm{mg} / \mathrm{L}$; $\mathrm{ZnSO}_{4} .7 \mathrm{H}_{2} \mathrm{O}-0.22 \mathrm{mg} / \mathrm{L} ; \quad \mathrm{CuCl}_{2} \cdot 2 \mathrm{H}_{2} \mathrm{O}-$ $0.05 \mathrm{mg} / \mathrm{L} ; \mathrm{VOSO}_{4} .2 \mathrm{H}_{2} \mathrm{O}-0.03 \mathrm{mg} / \mathrm{L}$; yeast extract- $1.0 \mathrm{~g} / \mathrm{L}$ at $\mathrm{pH} 1.8$ and $70{ }^{\circ} \mathrm{C}$. This archaea bacteria was able to oxidize Fe (II) to Fe (III) from its ability to grown proficiently in presence of pyrite. The enriched culture was subsequently adapted thrice on $5 \%$ $(\mathrm{w} / \mathrm{w})$ chalcopyrite ore $(<50 \mu \mathrm{m})$ in above medium under conditions of isolation.

\subsection{Bioleaching experiments}

The leaching experiments were carried out in Erlenmeyer flasks in an incubator shaker. A $200 \mathrm{~mL}$ of slurry containing ore $(40 \mathrm{~g})$ was inoculated with $10 \%(\mathrm{v} / \mathrm{v})$ of enriched adapted culture. Conditions such as $70 \pm 0.2{ }^{\circ} \mathrm{C}$ temperature, $\mathrm{pH} 1.8,20 \%$ (w/v) pulp density (PD) with shaking at $120 \mathrm{rpm}$ were maintained for leaching in 

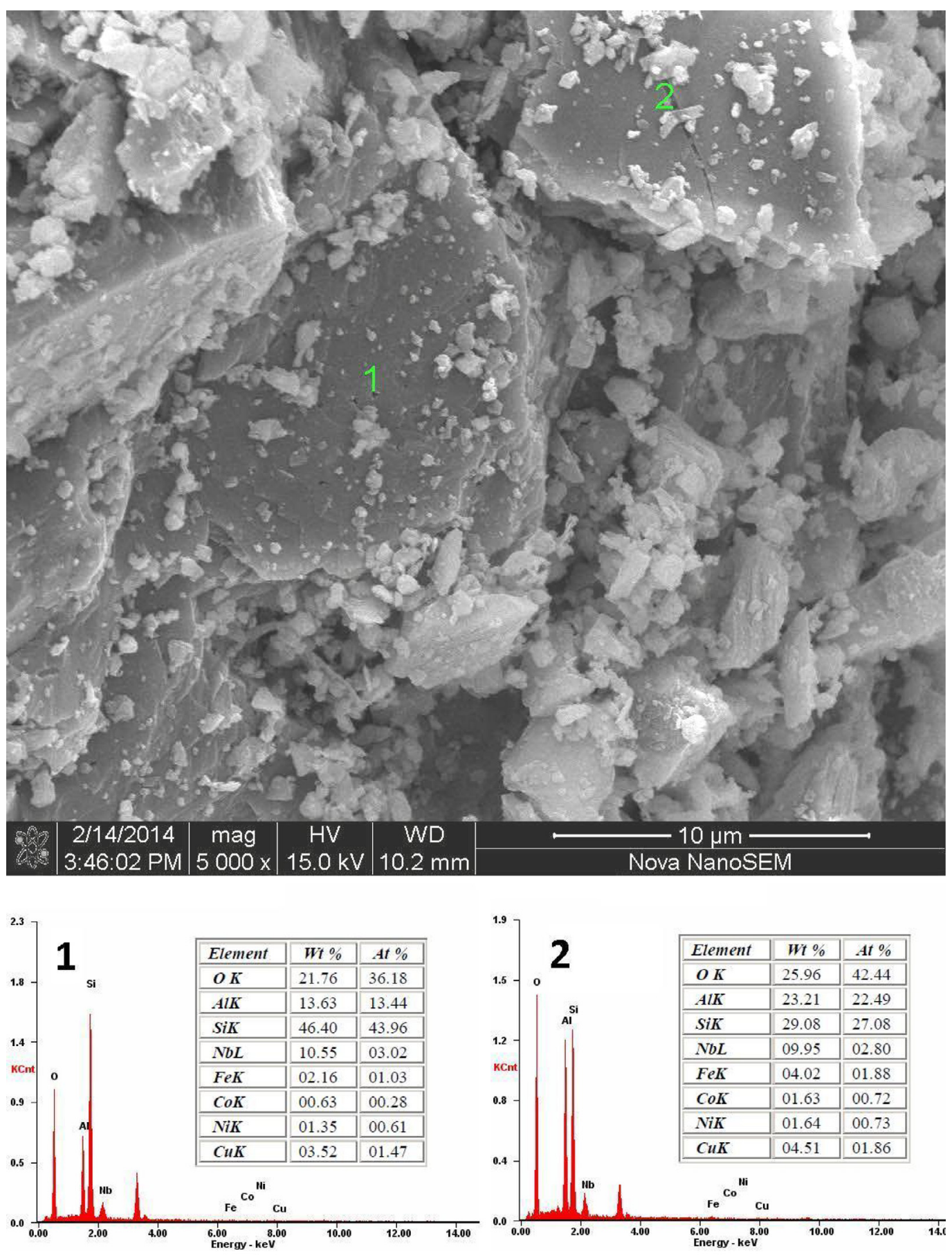

Fig. 1. SEM of $<50 \mu \mathrm{m}$ fraction of granitic Malanjkhand copper ore with elemental analysis.

high-temperature incubator-shaker (MakeInfors ${ }^{\mathrm{TM}}$ ) unless otherwise stated. A known amount of sample was drawn at 5 days interval for analysis of metals leached out by AAS. All the inoculated sets had their corresponding sterile control sets prepared under the same condition with $0.02 \mathrm{~g} / \mathrm{L} \mathrm{HgCl}_{2}$ added as bactericide and ferric ion added to mimic that produced by microbial iron oxidation. Ferrous ion concentration was analysed by titration against $\mathrm{N} / 20$ potassium dichromate solution. The $\mathrm{pH}$ of the leach solution was maintained daily with $5 \mathrm{M}$ sulfuric acid. Redox potential was measured 


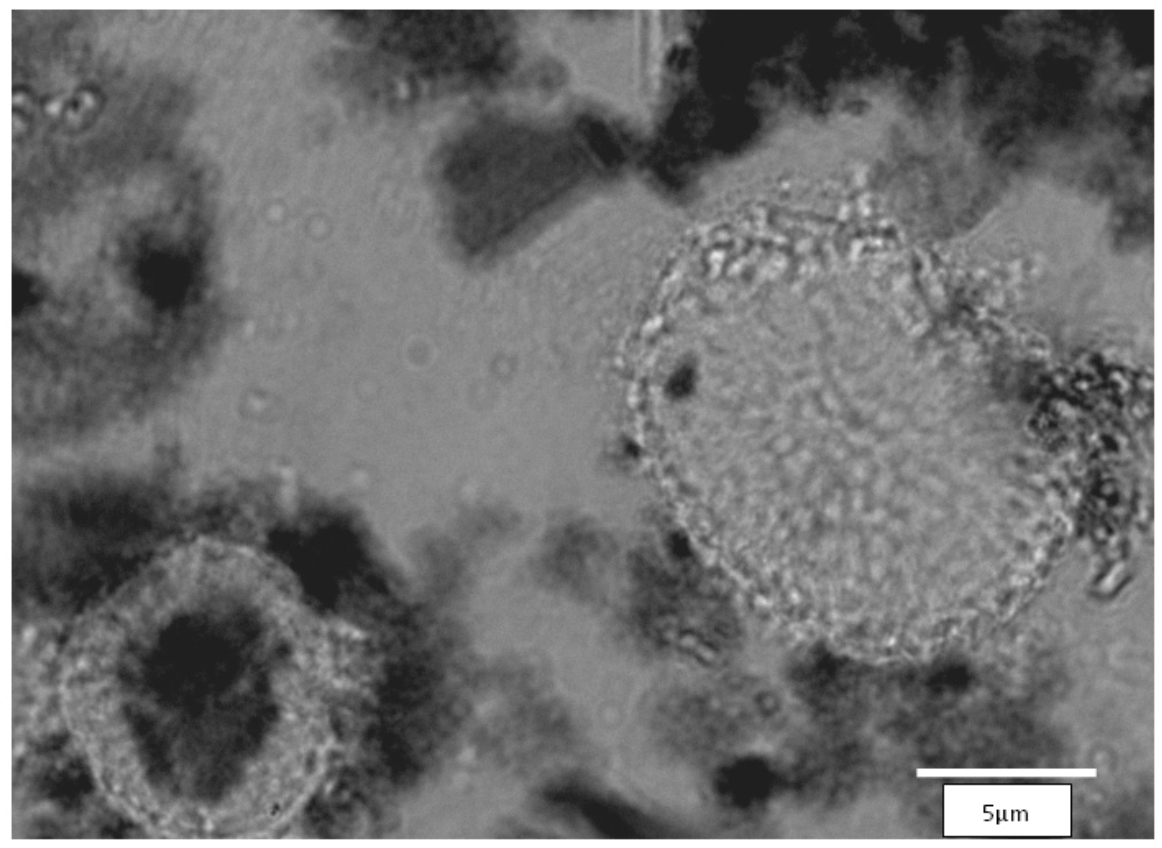

Fig. 2. Hyperthermophilic pure and enriched isolate at $70^{\circ} \mathrm{C}$ and $\mathrm{pH} 1.8$ in 10 days after $3 \mathrm{rd}$ sub-culturing.

against SCE. On completion of the leaching experiment, the slurry was filtered on Whatman Filer Paper (No. 42) and solid residue was dried. The representative sample of the residue was chemically analysed and the phases were identified by XRD and SEM.

\section{Results and discussion}

\subsection{Microbial isolation and culturing}

The morphological characteristics of isolate were studied under Motorized materialcum-biological microscope (Make-Leica ${ }^{\mathrm{TM}}$ ). Light and electron microscopy were used in order to investigate the morphological changes of the cells when grown in iron oxidizing medium and also under adaptive environment. The cells were negatively stained and observed with an oil immersion objective of 100/1.6. Bacterial cells growing a oval cells with shinning boundaries later grew in 12 days as big haloes of above $10 \mu \mathrm{m}$ crosssectional diameter as shown in Figure 2 with a rise in redox potential from $274 \mathrm{mV}$ to $439 \mathrm{mV}$. Regular sub-culturing in 12 days ensured faster growth kinetics of cells and potency for oxidation of Fe (II) as its concentration decreased from $2.25 \mathrm{~g} / \mathrm{L}$ to zero in
8 days of incubation. The increase in redox potential may be attributed to the improved oxidation of $\mathrm{Fe}$ (II) present in the solution because of bacteria present in it.

\subsection{Microbial adaptation}

The isolate was grown in presence of $0.5 \% \mathrm{w} / \mathrm{w}$ pyrite in medium with out iron source at similar conditions. The bacteria have a faster growth rate (Fig. 3a) with the artificially supplemented source of pyrite, thus proving its selectivity and initiating our interest to pursue this work. The pyrite grown species were then grown in $5 \% \mathrm{w} / \mathrm{w}$ chalcopyrite ore $(<50 \mu \mathrm{m})$ in presence of medium at first stage and then without medium in subsequent three stages at $\mathrm{pH} 1.8-2.0$ and $70^{\circ} \mathrm{C}$. There was a visible growth in presence of ore (containing pyrite as a major phase), aiding microbial proliferation (Fig. 3b).

\subsection{Optimization of bioleaching parameters}

Various parameters like $\mathrm{pH}$, pulp density, particle size and temperature were varied to test their influence on leaching of copper from low grade ore. 


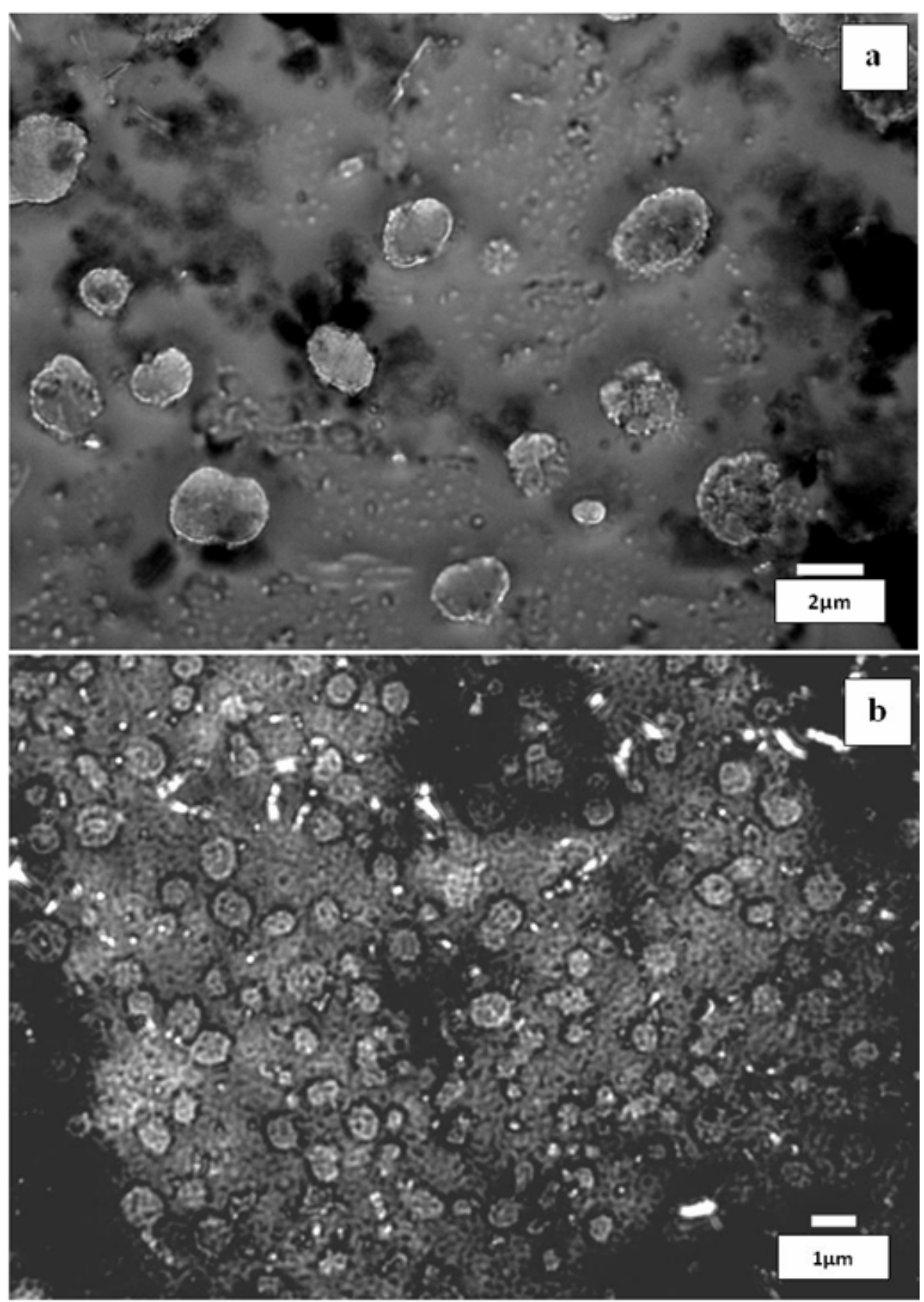

Fig. 3. Hyperthermophilic pure and enriched isolate adapted on (a) pyrite in 7 days, (b) ore in 10 days, at $70{ }^{\circ} \mathrm{C}$ and $\mathrm{pH} 1.8-2.0$.

\subsubsection{Effect of $\mathrm{pH}$}

Experiments were conducted by varying $\mathrm{pH}$ in the range $1.5-2.5$ at $10 \%(\mathrm{w} / \mathrm{w}) \mathrm{PD}$ with $<50 \mu \mathrm{m}$ particles at $70{ }^{\circ} \mathrm{C}$ as shown in Figure 4 . The extraction of copper increases with increase in $\mathrm{pH}$ up to 1.8 and descends at 2.0 to 2.5. It was recorded that enriched isolate could leach $78 \%$ Cu (Fig. 4a) in 25-30 days of incubation at $\mathrm{pH} 1.8$ (there was hardly any change in recovery after 25 days) with rise in redox potential from $438-653 \mathrm{mV}$. Whereas, copper bioleaching recorded 58\%, $72 \%, 66 \%$ and $60 \%$ recoveries at $1.5,2.0,2.2$ and $2.5 \mathrm{pH}$ respectively. When compared to chemical leaching (Fig. 4b), a maximum recovery of $11.78-16 \%$ Cu was observed under same conditions at $\mathrm{pH}$ 1.5-1.8. The metal recovery was very low at low $\mathrm{pH}$ because of lower oxidation potential of leaching system 

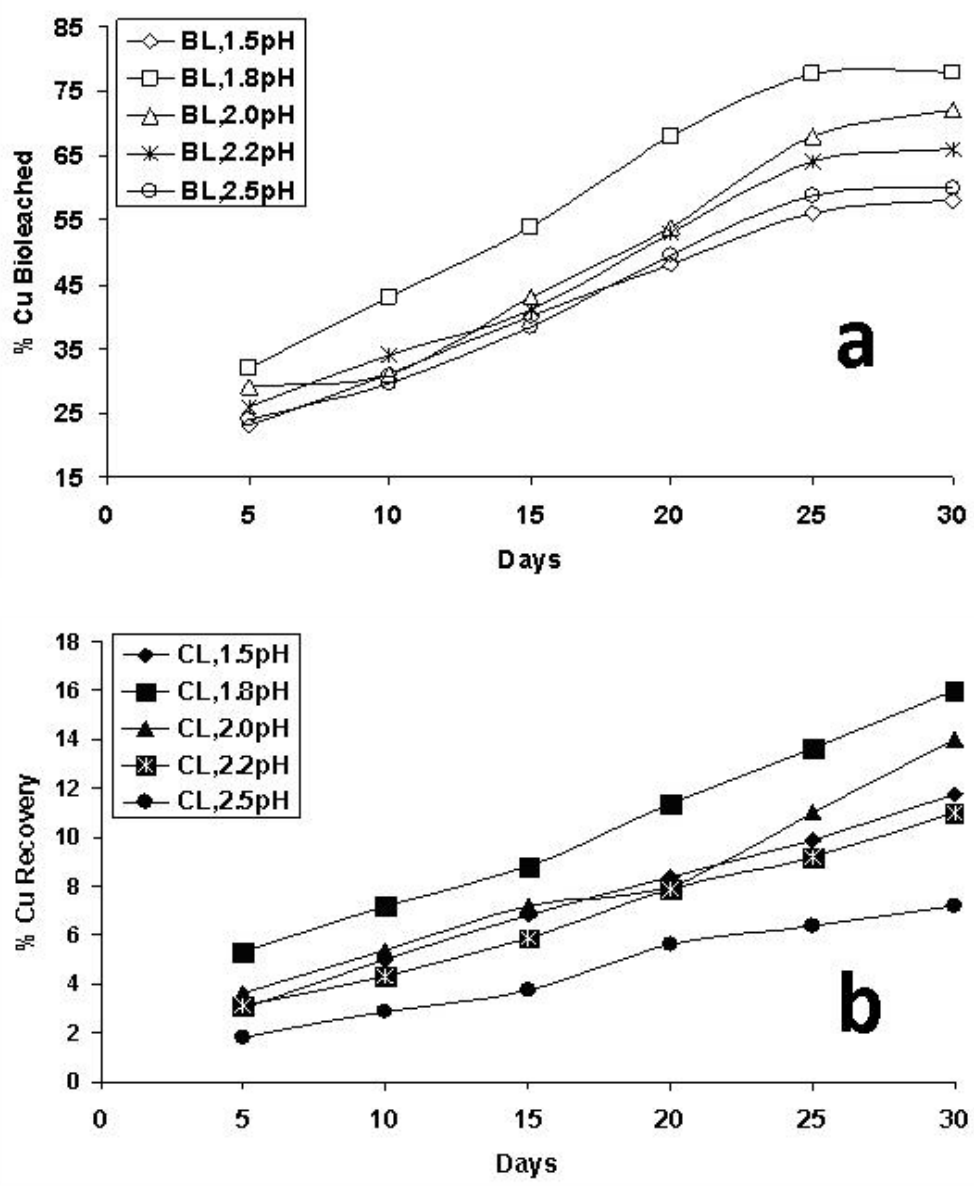

Fig. 4. Variation in copper recovery with change in $\mathrm{pH}$ at $10 \% \mathrm{PD}$ using $<50 \mu \mathrm{m}$ particles at $70{ }^{\circ} \mathrm{C}$; (a) Bioleaching (BL), (b) Chemical Leaching (CL).

and decreased activity of bacteria. Increasing the $\mathrm{pH}$ to 2.5 reduced the solubilisation of copper which may be due to the precipitation of high amount of iron (III) as hydronium jarosite [25], which was observed from the XRD phase identification studies. The lower metal bio-recovery (58\%) may be further correlated with the lower value of redox potential $(509 \mathrm{mV})$ at $2.5 \mathrm{pH}$. High metal bio-recovery $(78 \%)$ at $\mathrm{pH} 1.8$ may be attributed to the enhanced level of oxidation of $\mathrm{Cu}$ (II) to soluble form by Fe (III) produced through bio-chemical action on the ore. On the other hand, lower iron oxidation rate in control experiments was responsible for lower metal recovery. The presence of low Fe (II) level and high amount of Fe (III) generated biogenically, yielding high copper recovery suggesting it to follow indirect leaching mechanism.
As the amount of sulphur in the copper ore is $2.83 \%$, auto-generation of acid is expected to be quite significant at $\mathrm{pH}$ 1.52.0. It was observed that initial acid requirement for leaching was sufficiently high which became significantly low after 5 days of leaching (figure not shown). The sterile control experiment carried out at $\mathrm{pH} 1.8$ consumed $75 \%$ more acid than in the bioleaching sets.

\subsubsection{Effect of pulp density}

Pulp density (PD) for the bioleaching of copper was varied in the range $5-30 \%(w / w)$ using ore particles of $<50 \mu \mathrm{m}$ (mixed) size using $10 \%(\mathrm{v} / \mathrm{v})$ adapted enriched culture, while shaking at $120 \mathrm{rpm}$ at $\mathrm{pH} 1.8$ and $70{ }^{\circ} \mathrm{C}$ temperature. Data presented in Figure 5 shows increase in metal dissolution 

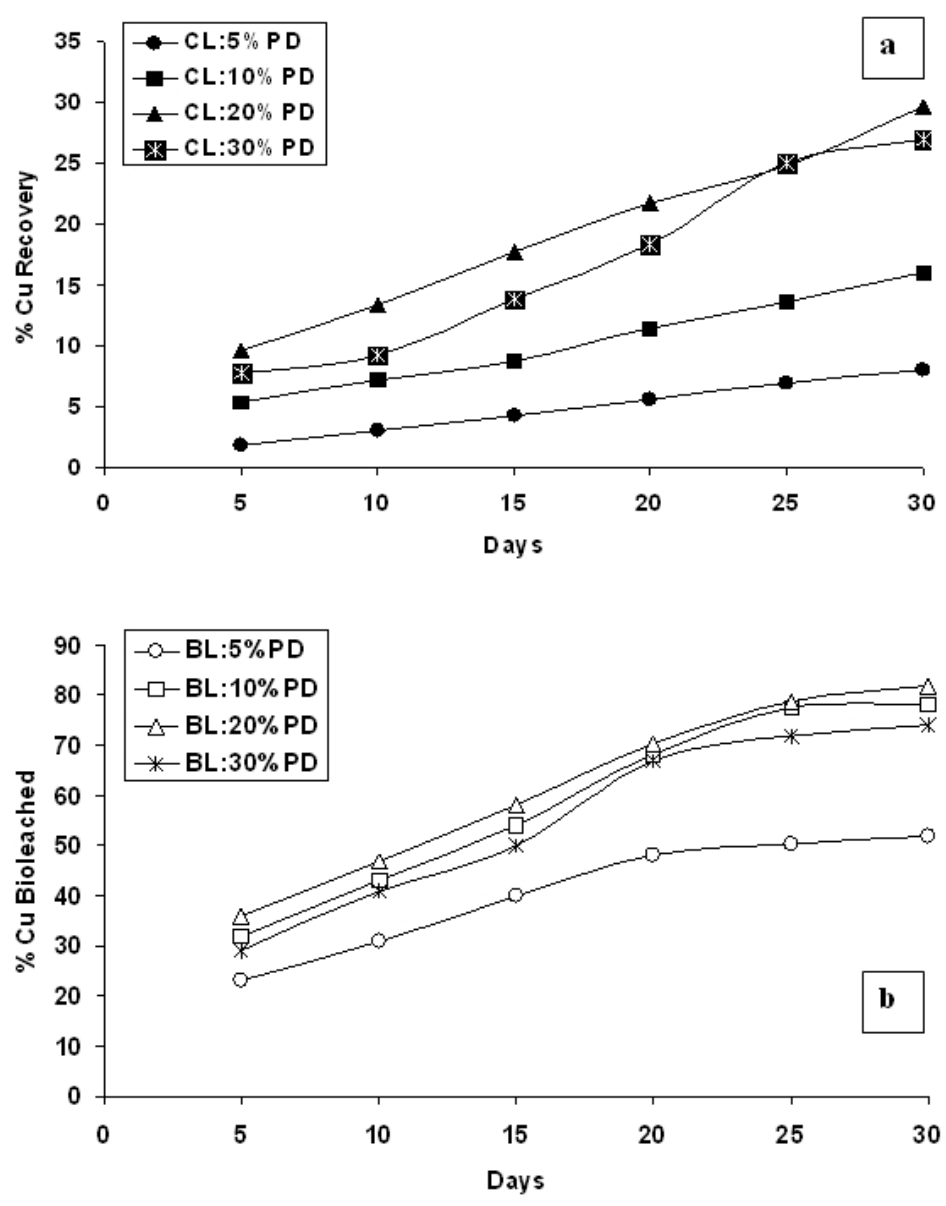

Fig. 5 . Variation in copper recovery with change in pulp density at $\mathrm{pH} 1.8$ using $<50 \mu \mathrm{m}$ particles at $70{ }^{\circ} \mathrm{C}$ (a) Chemical Leaching (CL), (b) Bioleaching (BL).

with time in both chemical and bioleaching experiments. At $5 \%$ pulp density, copper extraction of $8 \%$ (Fig. 5a) and $52 \%$ (Fig. $5 b$ ) were obtained in 30 days in chemical and bioleaching respectively. This shows the efficacy of bacteria to work at higher pulp ratio when compared to the results with mesophiles [5,6]. On further increasing the pulp density to $10 \%$ and $20 \%$, the copper biorecovery was found to increase from $78 \%$ to $82 \%$ (Fig. $5 \mathrm{~b}$ ) with corresponding chemical leaching (Fig. 5a) of $58 \%$ and $68 \%$. The rise in redox potential (Fig. 6) was observed from 443 to $693 \mathrm{mV}$ in bioleaching and 366 to $413 \mathrm{mV}$ in control leaching for 20\% PD in 30 days.

At still higher pulp density of $30 \%(\mathrm{w} / \mathrm{v})$ under the above conditions, the bio-recovery decreased to $74 \%$ (Fig. $5 \mathrm{~b}$ ) because of lower ratio of inoculum to substrate which may be attributed to the lack of oxygen availability and increased concentration of metal ions causing toxicity to bacterial growth at higher pulp densities [26]. Copper leaching in sterile set (control) was also lower at higher pulp densities. Thus, in further experiments, $20 \%$ pulp density was maintained.

\subsubsection{Effect of particle size}

Studies on effect of particle size $(>150 \mu \mathrm{m}$, $76-50 \mu \mathrm{m}$ and $<50 \mu \mathrm{m}$ ) as shown in Figure 7 indicates the suitability of fine size fraction $(<50 \mu \mathrm{m})$ which recorded maximum $(82 \%)$ copper biodissolution at $20 \%(\mathrm{w} / \mathrm{w}) \mathrm{PD}, \mathrm{pH}$ 1.8 , and temperature $70{ }^{\circ} \mathrm{C}$. It was correlated with the \% $\mathrm{Cu}$ existing in this fraction which accounted to be $0.32 \%$, whereas it was $0.17 \%$ and $0.29 \%$ in case of coarser 


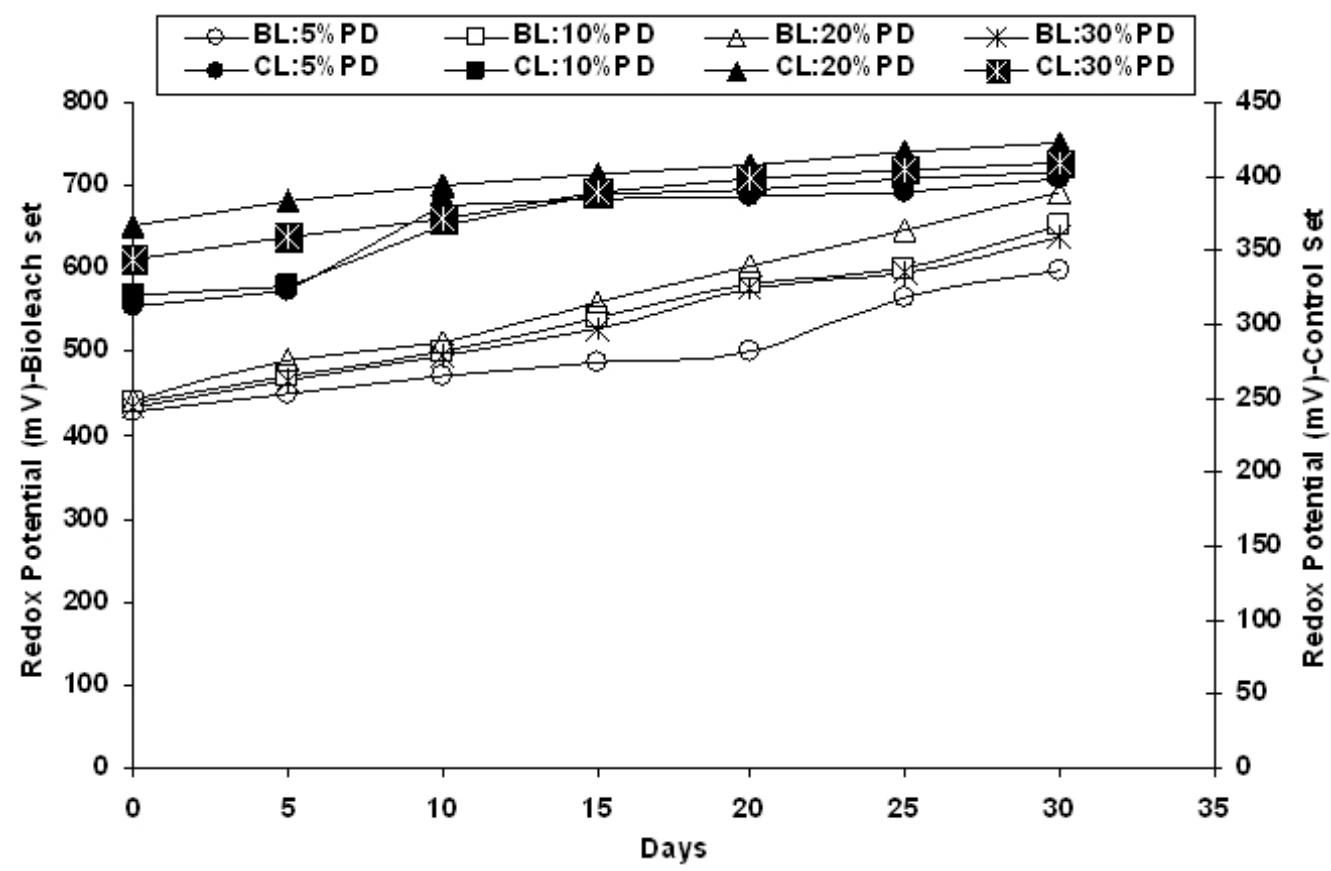

Fig. 6. Variation in redox potential under changing pulp densities at $\mathrm{pH} 1.8$ using $<50 \mu \mathrm{m}$ particles at $70{ }^{\circ} \mathrm{C}$ (a) Chemical Leaching (CL), (b) Bioleaching (BL).

$(<150 \mu \mathrm{m})$ and mid-size $(76-50 \mu \mathrm{m})$ particles respectively. This could be also be attributed to better permeation of the leachant to oxidize the copper sulphide present in the ore and increased surface area. Finer particles were increasingly exposed to lixiviant that dissolved copper from the chalcopyrite phase [27]. The concentration of ferric ions, oxidized by bacterial action on ferrous ions involved in chemically dissolving the metals was much higher in case of leaching of finer size than in case of coarser $(<150 \mu \mathrm{m})$ and mid-size $(76-50 \mu \mathrm{m})$ particles. The lower copper recovery of $67 \%$ and $70 \%$ was recorded for the coarser $(<150 \mu \mathrm{m})$ and mid-size (76-50 $\mu \mathrm{m}$ ) particles (Fig. 7).

Copper bio-recovery may be correlated with the change in concentration of ferrous ions and the redox potential values as plotted in Figure 8. Ferrous ion concentration was high $(0.47 \mathrm{~g} / \mathrm{L})$ which completely oxidizes to ferric state in 25 days (Fig. 8) for $<50 \mu \mathrm{m}$ size particles whereas different oxidation pattern for Fe (II) was observed for other size fractions. Also, the high value of redox potential $(695 \mathrm{mV})$ was attained for finer particles, which resulted in higher recovery.

\subsubsection{Effect of temperature}

Rise in reaction temperature (in the range $50-75^{\circ} \mathrm{C}$ ) led to an increase of copper bioleaching at $\mathrm{pH} 1.8$ and $20 \%$ (w/w) PD using $10 \%(\mathrm{v} / \mathrm{v})$ enriched and adapted culture with $<50 \mu \mathrm{m}$ particles as shown in Figure 9. A maximum metal bio-dissolution of $85 \% \mathrm{Cu}$ was recorded at $75{ }^{\circ} \mathrm{C}$ as compared to other three temperatures i.e. $59 \%$ at $50{ }^{\circ} \mathrm{C}, 63 \%$ at $60{ }^{\circ} \mathrm{C}$ and $74.2 \%$ at $65{ }^{\circ} \mathrm{C}$ respectively. The slight rise in recovery of raising the temperature can be attributed to the extremophilic nature and the resistance developed by these species. When compared with the data for chemical leaching sets, a maximum of $38 \%$ $\mathrm{Cu}$ was recovered at $75^{\circ} \mathrm{C}$, with corresponding recovery of $29 \%$ at $50{ }^{\circ} \mathrm{C}, 31 \%$ at $60{ }^{\circ} \mathrm{C}$ and $35 \%$ at $65{ }^{\circ} \mathrm{C}$ respectively in same time period.

During bioleaching at $75{ }^{\circ} \mathrm{C}$, redox potential varied from 452 to $701 \mathrm{mV}$ in 30 days (Fig. 10) inferring to the role of cell interactions with mineral phase and simultaneous rise in redox potential, causing higher metal dissolution. It thus indicates the ability to grown preferentially at high iron concentration in lesser time thereby promoting 


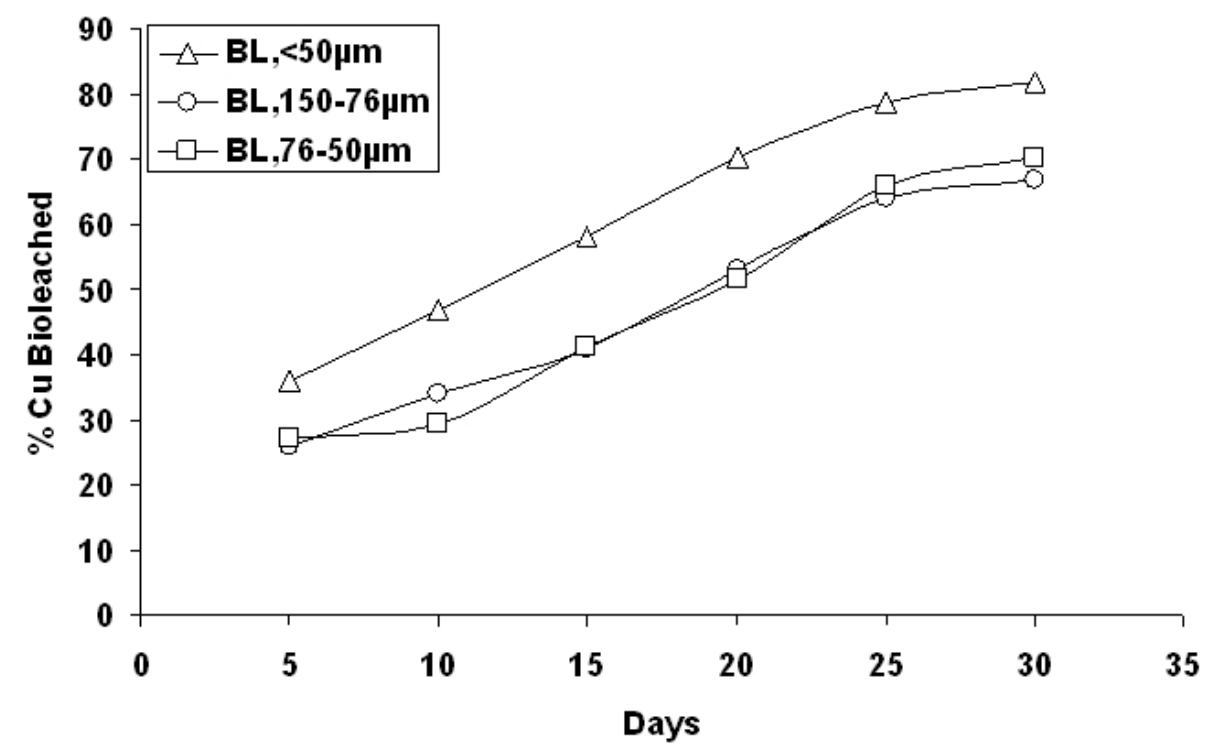

Fig. 7. Variation in copper biorecovery by enriched-adapted Sulfolobus strain with change in particle size at $\mathrm{pH} 1.8,20 \% \mathrm{PD}, 70^{\circ} \mathrm{C}$.

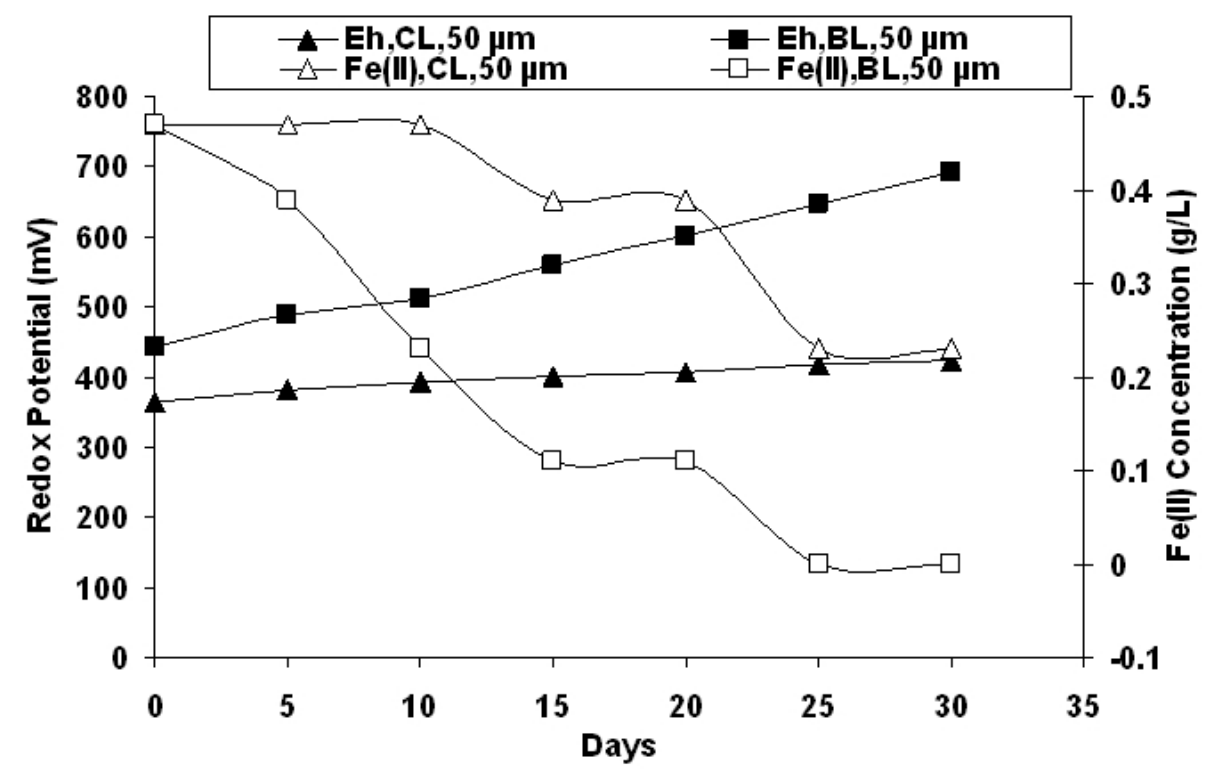

Fig. 8. Variation in redox potential with change in ferrous ion concentration at $\mathrm{pH} 1.8 \mathrm{using}<50 \mu \mathrm{m}$ particles at $70{ }^{\circ} \mathrm{C}$ (a) Chemical Leaching (CL), (b) Bioleaching (BL).

the rate of copper bio-dissolution [5, 6]. Chemical leaching was also performed at the optimized temperature to understand the passivation behaviour of chalcopyrite in presence and absence of bacteria, which gave a maximum recovery of $77 \%$ (data shown in Fig. 5a). It has been earlier reported that mesophilic bioleaching using adapted enriched culture of $A$. ferrooxidans extracted $75 \% \mathrm{Cu}$ at $35^{\circ} \mathrm{C}[2,5]$.

\subsubsection{Kinetics of chalcopyrite bioleaching by Sulfolobus}

The rate of chalcopyrite bio-dissolution was tested against shrinking core models through diffusion control, chemical control, and mixed control. Kinetic data showed a good fit (Fig. 11) to the diffusion controlled model according to Equation (3)

$$
1-2 / 3 x-(1-x)^{2 / 3}=k_{d} t \text {. }
$$




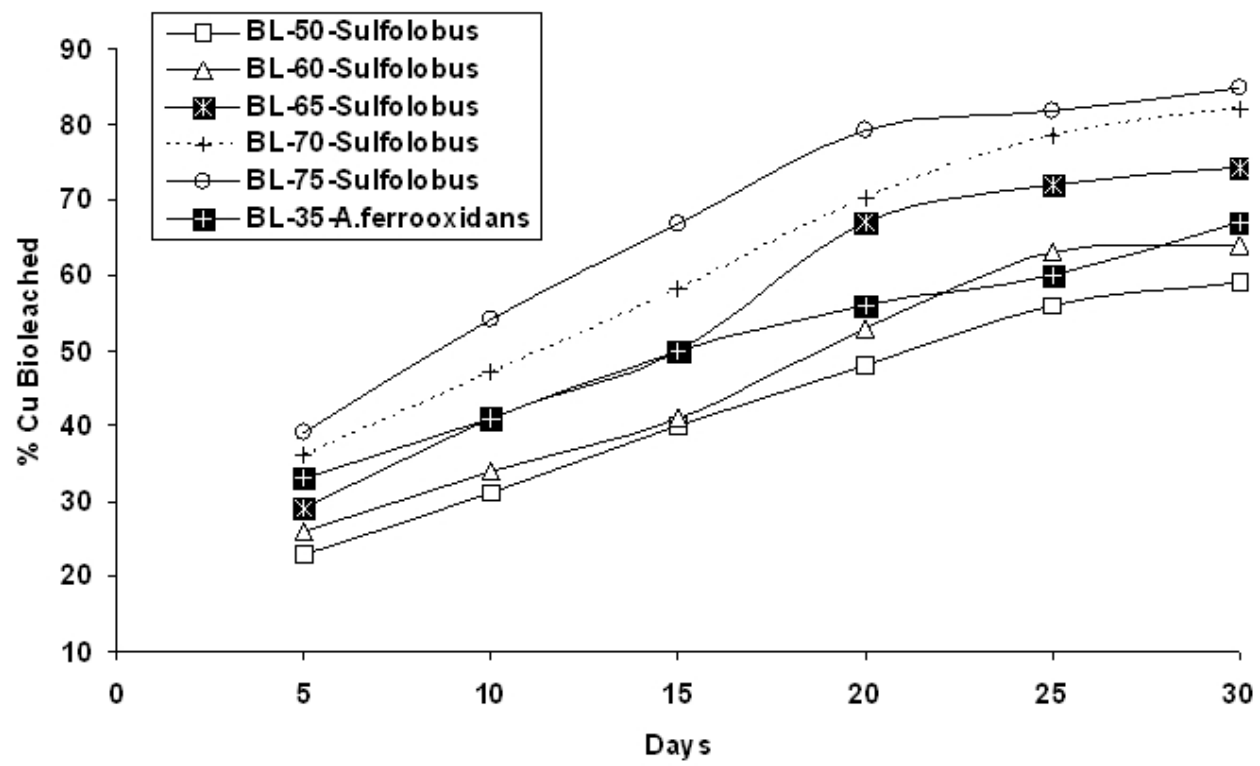

Fig. 9. Variation in copper biorecovery with change in temperature at $\mathrm{pH} 1.8,20 \% \mathrm{PD}$ using $<50 \mu \mathrm{m}$ particles.

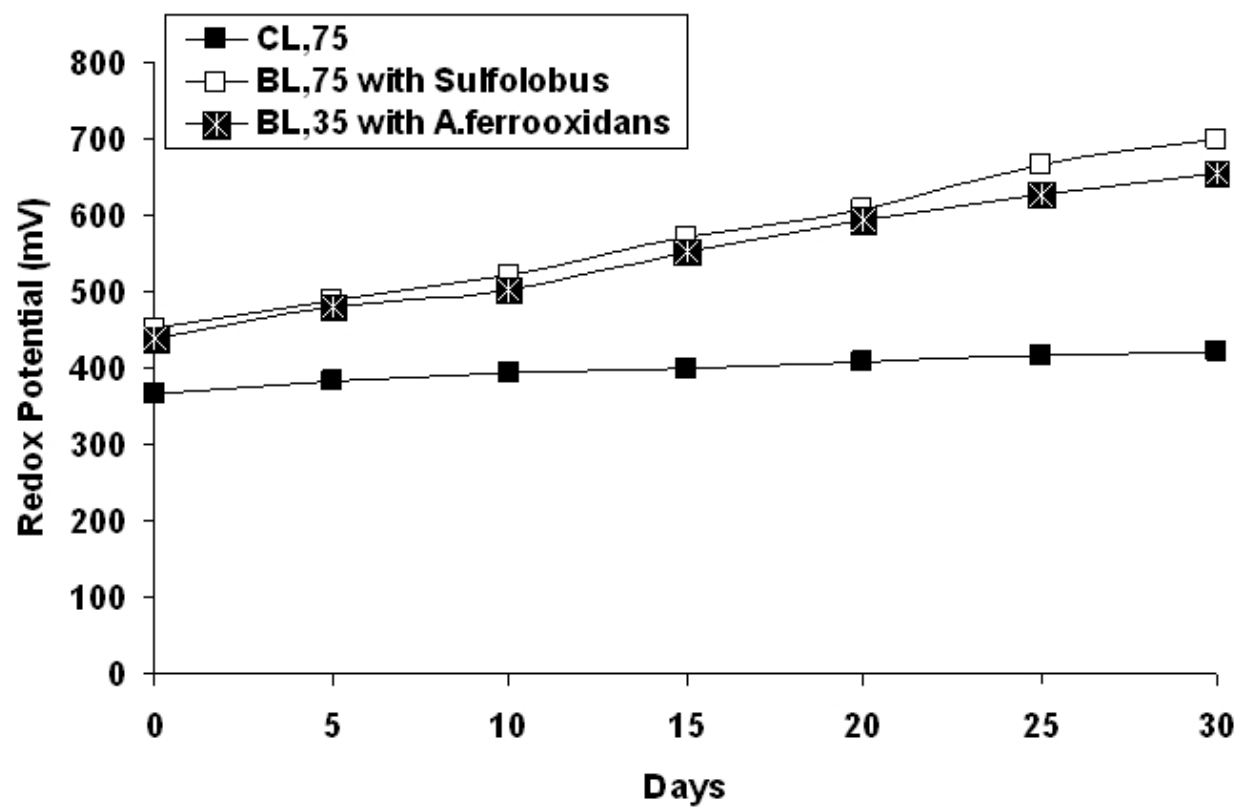

Fig. 10. Variation in redox potential using $<50 \mu \mathrm{m}$ particles at $35{ }^{\circ} \mathrm{C}$ (A. ferrooxidans) and $75{ }^{\circ} \mathrm{C}$ (in presence and absence of Sulfolobus).

The dissolution of copper proceeded by the diffusion of Fe (III) as the lixiviant generated bio-genically, through the porous product layer possibly of the jarosite formed on the ore particles [10-13]. The rate constant values for the diffusion controlled bioleaching of copper with hyperthermophiles were obtained from Figure 11 as 0.0052,
$0.0044,0.0032,0.0022$, and $0.0018 \mathrm{~d}^{-1}$ at $50{ }^{\circ} \mathrm{C}$ $(324 \mathrm{~K}), 60{ }^{\circ} \mathrm{C}(333 \mathrm{~K}), 65^{\circ} \mathrm{C}(338 \mathrm{~K}), 70{ }^{\circ} \mathrm{C}$ $(344 \mathrm{~K})$ and $75{ }^{\circ} \mathrm{C}(348 \mathrm{~K})$ respectively. The plots of rate constant values $\left(k_{d}\right)$ with the reciprocal of $r^{2}$ ( $r$ being the size of the particles used) in the temperature range 324-348 K (not given here) which further confirmed that the copper bio-leaching followed the 


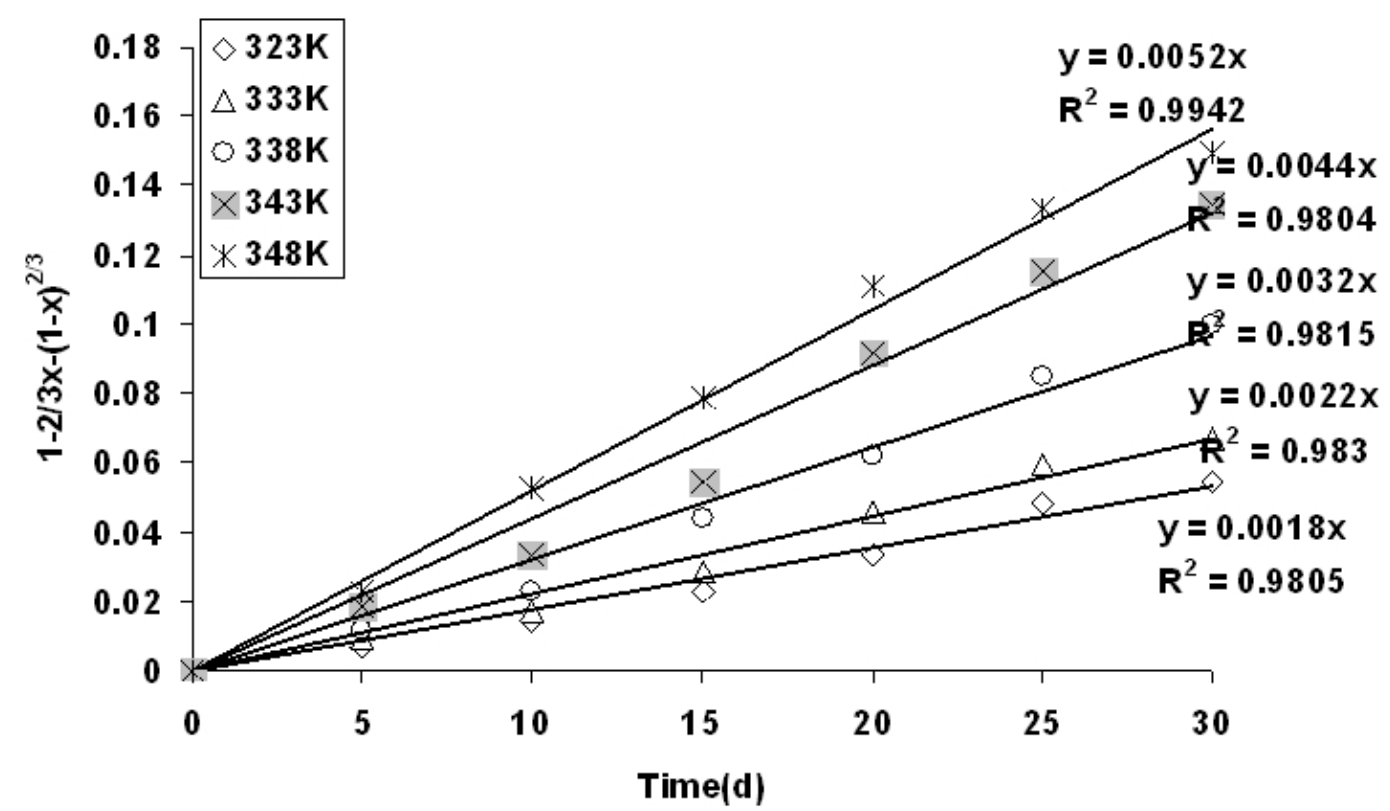

Fig. 11. Diffusion Control model for bioleaching of chalcopyrite using hyperthermophiles (323-348 K).

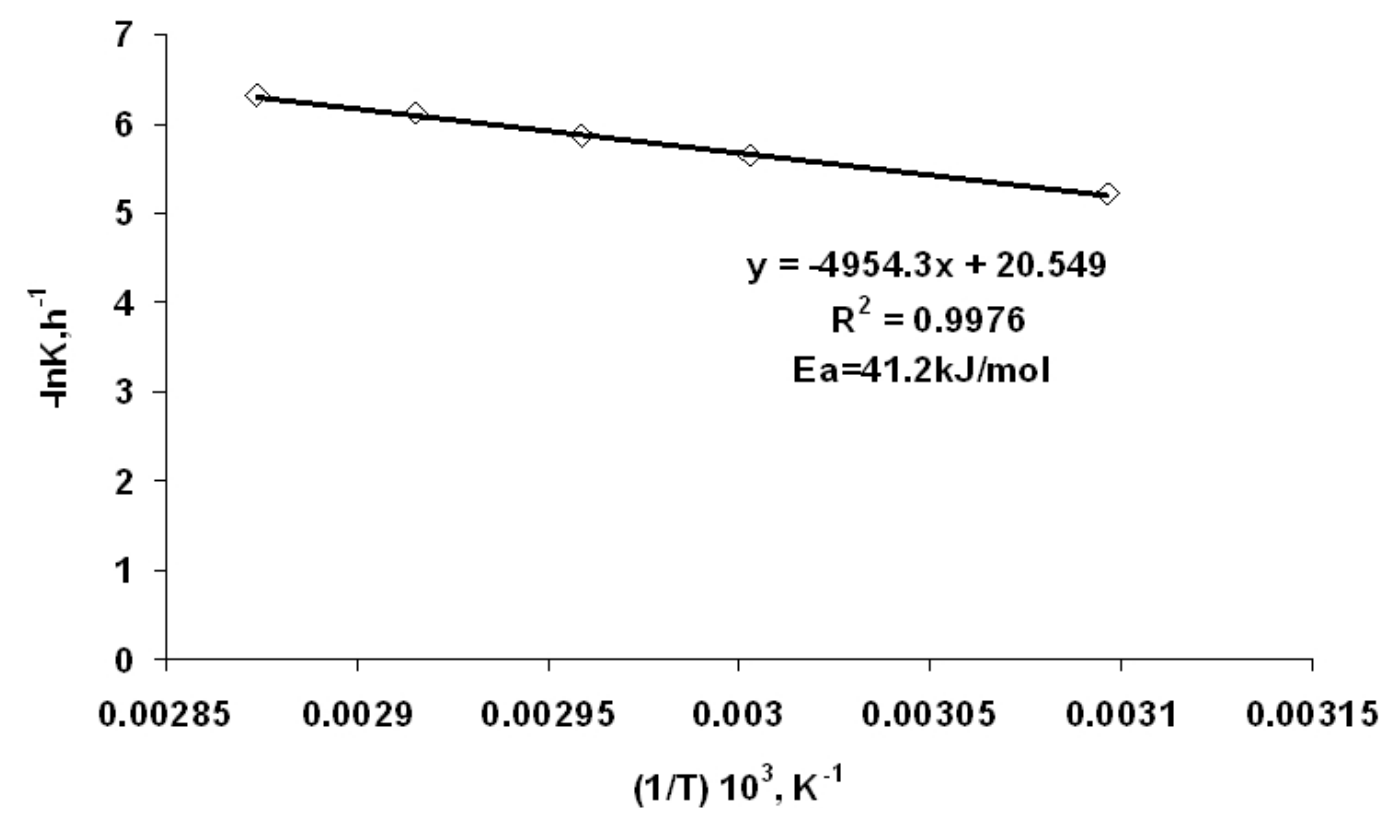

Fig. 12. Arrhenius plot for bioleaching of chalcopyrite using hyperthermophiles (323-348 K).

diffusion controlled model [5]. The activation energy values $\left(E_{a}\right)$ were calculated from the Arrhenius plot (Fig. 12) and was found to be $41.2 \mathrm{~kJ} / \mathrm{mol}$ under the temperature range $324-348 \mathrm{~K}$ at $1.8 \mathrm{pH}$. The kinetics didn't follow other models and hence not shown.

The XRD data of the leach residue generated in presence of absence of hy- perthermophiles vis-à-vis mesophiles was analyzed. At $35{ }^{\circ} \mathrm{C}$, hydronium jarosite $\left[\mathrm{H}_{3} \mathrm{OFe}_{3}\left(\mathrm{SO}_{4}\right)_{2}(\mathrm{OH})_{6}\right]$ and quartz were present as major phases [28] and chalcopyrite and pyrite as the minor phases. At $75^{\circ} \mathrm{C}$ with hyperthermophiles, the presence of pyrite in minor phase couldn't be accounted due to very low intensity, whereas elemental 

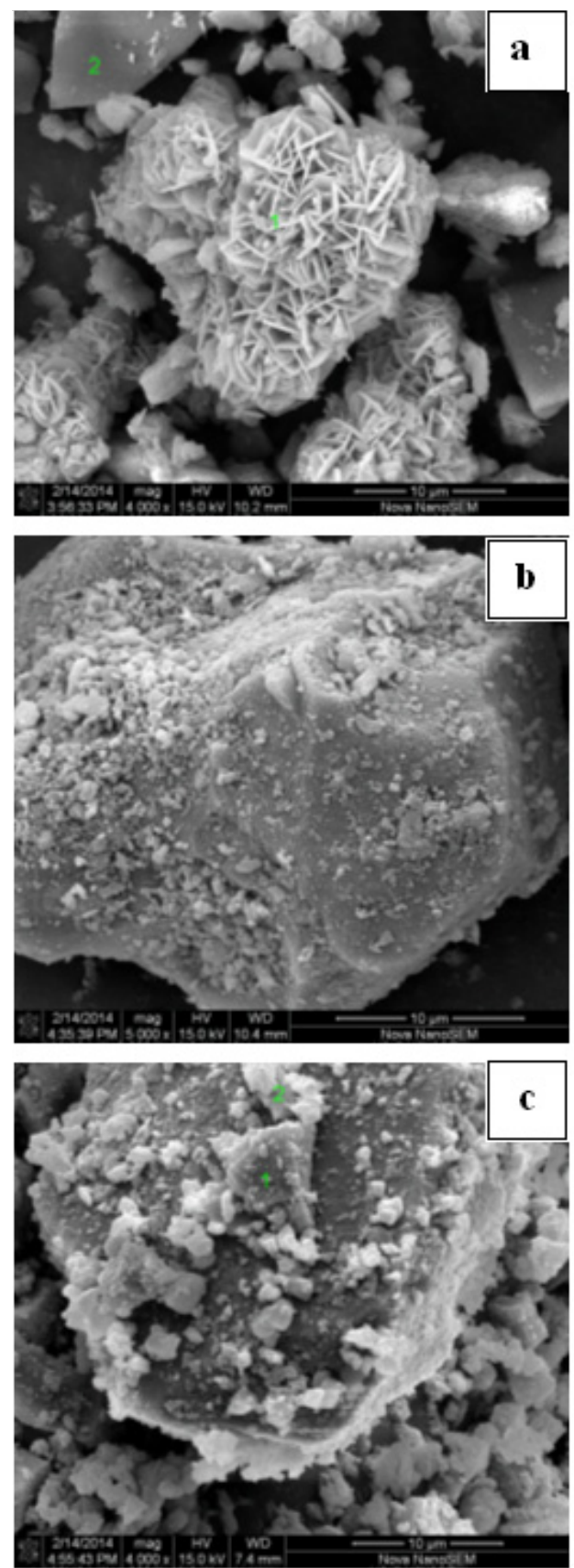

\begin{tabular}{|c|c|c|c|c|}
\hline \multirow[t]{2}{*}{ Element } & \multicolumn{2}{|c|}{ Point-1 } & \multicolumn{2}{|c|}{ Point 2} \\
\hline & $W t \%$ & At \% & $W t \%$ & $A t \%$ \\
\hline$O K$ & 07.98 & 15.03 & 17.56 & 30.29 \\
\hline$A I K$ & 01.31 & 01.46 & 01.80 & 01.84 \\
\hline SiK & 66.46 & 71.27 & 58.49 & 57.49 \\
\hline $\bar{K} K$ & 00.90 & 00.69 & 01.71 & 01.21 \\
\hline $\mathrm{FeK}$ & 03.30 & 01.78 & 02.54 & 01.25 \\
\hline $\mathrm{CoK}$ & 02.71 & 01.38 & 01.95 & 00.91 \\
\hline$N I K$ & 04.11 & 02.11 & 02.15 & 01.01 \\
\hline $\mathrm{CuK}$ & 13.24 & 06.27 & 13.80 & 05.99 \\
\hline
\end{tabular}

Fig. 13. SEM micrographs of leach residue after (a) bioleaching with Sulfolobus at $75{ }^{\circ} \mathrm{C}$, (b) bioleaching at $35{ }^{\circ} \mathrm{C}$ with $A$. ferrooxidans, (c) chemical leaching with $\mathrm{H}_{2} \mathrm{SO}_{4}$ at $75{ }^{\circ} \mathrm{C}$. iron was seen. At high temperature without bacteria, along with quartz, pyrite and ferrosilite existed in the major phase.

The mechanism of bio-chemical leaching of copper was further investigated by observing the surface morphology through SEM-EDX (Fig. 13) at various conditions. SEM image of the leach residue at $75{ }^{\circ} \mathrm{C}$

\begin{tabular}{||l|c|c|c|c||}
\hline \multirow{2}{*}{ Element } & \multicolumn{2}{|c|}{ Point- 1} & \multicolumn{2}{c|}{ Point-2 } \\
& Wt\% & At \% & Wt \% & At \% \\
\hline O $\boldsymbol{K}$ & 16.57 & 39.94 & 07.12 & 13.98 \\
\hline AIK & 02.44 & 03.48 & 13.81 & 16.09 \\
\hline SiK & 07.83 & 10.75 & 50.47 & 56.47 \\
\hline NbL & 14.78 & 06.13 & 08.42 & 02.85 \\
\hline FeK & 49.32 & 34.05 & 06.40 & 03.60 \\
\hline CoK & 01.27 & 00.83 & 02.63 & 01.40 \\
\hline NiK & 01.74 & 01.14 & 02.27 & 01.21 \\
\hline CuK & 06.06 & 03.68 & 08.89 & 04.40 \\
\hline \hline
\end{tabular}

\begin{tabular}{|l|c|c|}
\hline Element & $W t \%$ & At \% \\
\hline OK & 07.07 & 13.61 \\
\hline AlK & 00.78 & 00.89 \\
\hline SiK & 65.98 & 72.38 \\
\hline FeK & 02.35 & 01.29 \\
\hline CoK & 02.40 & 01.25 \\
\hline NIK & 04.56 & 02.39 \\
\hline CuK & 16.87 & 08.18 \\
\hline \hline
\end{tabular}

with Sulfolobus (Fig. 13a) exhibits extensive corrosion and rise in copper dissolution in 30 days with formation of floral patterned structures rich in iron. On the other hand, surface morphology (Fig. 13b) in 30 days leaching at $35^{\circ} \mathrm{C}$ with $A$. ferrooxidans doesn't indicate much corrosion. Extensive formation of hydronium jarosite could be easily 
seen on the surface of chemically leached ore sample (Fig. $13 \mathrm{c}$ ) in 30 days at $75^{\circ} \mathrm{C}$, thereby indicating the relative low copper recovery. On comparing these results wit our earlier attempts by mesophiles [5]; it's very evident for the definite future of hyperthermophiles to exploit such low tenor materials.

\section{Conclusions}

- The extremely thermophilic archaea strain isolated from coal mine sample able to degrade pyritic sulfur, was sequentially adapted on chalcopyrite ore of Malanjkhand copper project.

- This enriched and adapted culture was used in the bioleaching experiment at $\mathrm{pH}$ $1.8,20 \% \mathrm{PD}$ and $75{ }^{\circ} \mathrm{C}$ temperature in 30 days time with the fine particles of $<50 \mu \mathrm{m}$ size gave $85 \%$ copper recovery.

- High metal recovery with the fine size particles $(<50 \mu \mathrm{m})$ may be attributed by the better permeability of ferric ions biogenically generated by bacterial action on pyrite to dissolve copper. Recovery of copper may be correlated with the values of redox potential acquired during the experiments.

- Under the optimum condition at pH 1.8 and $75{ }^{\circ} \mathrm{C}$ temperature, rise in redox potential was recorded to be $452-701 \mathrm{mV}$ in 30 days.

- The XRD data of the leach residue generated in presence of absence of hyperthermophiles vis-à-vis mesophiles showed hydronium jarosite $\left[\mathrm{H}_{3} \mathrm{OFe}_{3}\left(\mathrm{SO}_{4}\right)_{2}(\mathrm{OH})_{6}\right]$ and quartz were present as major phases at $35{ }^{\circ} \mathrm{C}$ and chalcopyrite and pyrite as the minor phases. With hyperthermophiles, along with quartz, pyrite and ferrosilite existed in the major phase. SEM characterization also corroborated the leaching efficiency, and confirmed bioleaching of copper from chalcopyrite ore to follow the indirect mechanism with the involvement of Fe (III) biogenically generated by the bacteria from the ore. These hyperthermophiles can be very useful for exploitation of such reserves from the perspective of the quantity vis-à-vis climate of tropical countries.

\section{References}

[1] N. Pradhan, K. Nathasharma, K.S. Rao, L.B. Sukla, B.K. Mishra, Minerals Eng. 21 (2007) 355-365

[2] H.R. Watling, Hydrometallurgy 84 (2006) 81108

[3] D.E. Rawlings, D.B. Johnson, Biomining. Springer, Berlin-Heidelberg, 2007

[4] Abhilash, K.D. Mehta, B.D. Pandey, Rem: Revista Escola de Minas 66 (2013) 245-250

[5] S. Singh, L.B. Sukla, B.K. Mishra, Indian J. Microbiol. 51 (2011) 477-481

[6] D. Bevilaqua, A.L.L.C. Leite, O. Garcia, O.H. Tuovinen, Process Biochem. 38 (2002) 587-592

[7] J.L. Mier, A. Ballester, M.L. Blázquez, F. González, J.A. Muñoz, Minerals Eng. 8 (1995) 949-965

[8] P. D'Hugues, S. Foucher, P. Gallé-Cavalloni, D. Morin, Int. J. Mineral Process. 66 (2002) 107-119

[9] M. Nemati, S.T.L. Harrison, Minerals Eng. 13 (2000) 19-24

[10] V.S.T. Ciminelli, O. Garcia Jr., Biohyd- rometallurgy: Fundamentals, Technology and Sustainable Development - Part A. Elsevier, Amsterdam, 2001

[11] M. Gerike, A. Pinches, J.V. Van-rooyen, Int. J. Mineral Process. 62 (2001) 243-255

[12] K.A. Third, R. Cord-Ruwisch, H.R. Watling, Hydrometallurgy 57 (2000) 225-233

[13] J. Petersen, D.G. Dixon, Minerals Eng. 15 (2002) 777-785

[14] A. Sissing, S.T.L. Harrison, J. South African Institute Mining Metallurgy 103 (2003) 139142

[15] J. Vilcaez, K. Suto, C. Inoue, Int. J. Mineral Process. 88 (2008) 37-44

[16] J. Vilcaez, K. Suto, C. Inoue, Minerals Eng. 21 (2008) 1063-1074

[17] C. Wu, W. Zeng, H. Zhou, B. Fu, J. Huang, G. Qiu, D. Wang, J. Central South University of Technology 14 (2007) 474-478

[18] J.C. Duarte, P.C. Estrada, P.C. Pereira, H.P. Beaumont, FEMS Microbiol. Rev. 11 (1993) 97-102

[19] Y. Konishi, S. Yoshida, S. Asai, Biotechnol. Bioeng. 48 (1995) 592-600

[20] P.R. Norris, D.W. Barr, Bacterial oxidation of pyrite in high temperature reactors, in: Norris P.R., Kelly D.P. (eds.), Proceedings of Biohydrometallurgy '87, Science and Technology Letters, U.K., 1988, pp. 532-536

[21] Y. Konishi, M. Tokushige, S. Asai, Bioleaching of chalcopyrite concentrate by acidophilic thermophile Acidianus brierleyi. In Proceedings of the International Biohydrometallurgy Symposium IBS'99. Elsevier, Amsterdam 1999, pp. 367-376

[22] F. Torres, M.L. Blázquez, F. González, A. Ballester, J.L. Mier, Metal. Mate. Trans. B 26 (199) 455-465 
[23] D. Howard, F.K. Crundwell, A kinetic study of the leaching of chalcopyrite with Sulfolobus metallicus. in Proceedings of the International Biohydrometallurgy Symposium IBS'99. Elsevier, Amsterdam 1999, pp. 209-218

[24] P.R. Norris, D.A. Clark, J.P. Owen, S. Waterhouse, Microbiology 142 (1996) 775-783
[25] B.K. Fu, H. Lin, X.L. Mo, Y.B. Dong, L. Zhou, J. Univ. Sci. Technol. 33 (2011) 806-811

[26] L. Larsson, G. Olsson, O. Hoist, H.T. Karlsson, Appl. Environ. Microbiol. 56 (1990) 697-701

[27] M. Nemati, S.T.L. Harrison, J. Chem. Technol. Biotechnol. 75 (2000) 526-532

[28] L. Xia, X. Liu, J. Zeng, C. Yin, J. Gao, J. Liu, G. Qiu, Hydrometallurgy 92 (2008) 95-101 